\title{
Rational use of antioxidants in solid oral pharmaceutical preparations
}

\author{
Maísa Teodoro Celestinoํㅜ ${ }^{1}$ Uiaran de Oliveira Magalhães ${ }^{1}$, Aline Guerra Manssour Fraga ${ }^{1}$, \\ Flávia Almada do Carmo ${ }^{1}$, Viviane Lione ${ }^{1}$, Helena Carla Castro ${ }^{2}$, Valeria Pereira de Sousa ${ }^{1}$, \\ Carlos Rangel Rodrigues ${ }^{1}$, Lucio Mendes Cabral ${ }^{1, *}$
}

\author{
${ }^{I}$ Departamento de Medicamentos, Faculdade de Farmácia, Universidade Federal do Rio de Janeiro, \\ ${ }^{2}$ LABioMol, Instituto de Biologia, Universidade Federal Fluminense
}

\begin{abstract}
Antioxidants are currently used as efficient excipients that delay or inhibit the oxidation process of molecules. Excipients are often associated with adverse reactions. Stability studies can guide the search for solutions that minimize or delay the processes of degradation. The ability to predict oxidation reactions in different drugs is important. Methods: This study was conducted to assess the rational use of butylated hydroxyanisole (BHA), butylated hydroxytoluene (BHT), sodium metabisulfite (SMB), propyl gallate $(\mathrm{PG})$ and cysteine (CYS) in tablet formulations of simvastatin and ketoconazole. These antioxidants were evaluated according to stability parameters and the relationship between efficiency of the antioxidant and chemical structure of the drugs. Results were compared with DPPH tests and computational simulations. BHT was most efficient regarding simvastatin stability, and the most effective BHT concentrations for maintaining stability were 0.5 and $0.1 \%$. In relation to ketoconazole, SMB was most efficient for maintaining content and dissolution profile. The evaluation by DPPH showed that the largest percentage of absorbance reduction was observed for PG, while SMB proved most efficient and had lower consumption of DPPH. The same pattern was observed, albeit with lower efficiency, for the other lipophilic antioxidants such as BHT and BHA. The results of the molecular modeling study demonstrated that electronic properties obtained were correlated with antioxidant activity in solution, being useful for the rational development of liquid pharmaceutical formulations but not for solid oral formulations. This study demonstrated the importance of considering stability parameters and molecular modeling to elucidate the chemical phenomena involved in antioxidant activity, being useful for the rational use of antioxidants in the development of pharmaceutical formulations.
\end{abstract}

Uniterms: Antioxidants/rational use. Excipients/evaluation. Butylated hydroxyanisole/rational use. Butylated hydroxytoluene/rational use. Sodium metabisulfite/rational use. Propyl gallate/rational use. Cysteine/rational use. Simvastatin/tablets/evaluation. Ketoconazole/tablets/evaluation.

Atualmente, antioxidantes são usados como excipientes eficientes, que retardam ou inibem o processo de oxidação de moléculas. Excipientes são frequentemente associados a efeitos adversos. Estudos de estabilidade podem ajudar na busca por possíveis soluções para minimizar ou retardar os processos de degradação. A habilidade de prever as reações de oxidação em diferentes fármacos é importante. O estudo foi conduzido com o objetivo de avaliar o uso racional de hidroxianisol butilado (BHA), hidroxitolueno butilado (BHT), metabissulfito sódico (SMB), galato de propila (PG) e cisteína (CYS) em formulações de comprimidos de sinvastatina e cetoconazol. Eles foram avaliados por parâmetros de estabilidade e pela relação entre a eficiência dos antioxidantes e a estrutura química do fármaco. Os resultados foram comparados com testes de DPPH e simulações em computador. BHT foi mais eficiente com relação a estabilidade da sinvastatina e às concentrações mais eficientes para manutenção de estabilidade foram 0,5 e $0,1 \%$. Com relação ao cetoconazol, SMB foi mais eficiente em manter o conteúdo e o perfil de dissolução. A avaliação por DPPH mostrou que o maior percentual de redução de absorção foi observado

Correspondence: L. M. Cabral. Departamento de Medicamentos - CCS, Faculdade de Farmácia, Cidade Universitária, Ilha do Fundão - 21941902 - Rio de Janeiro - RJ, Brazil. Phone: +55 21-2562-6605. E-mail: lmcabral@pharma.ufrj.br 
para PG, enquanto que SMB mostrou ser mais eficiente e consumir menos DPPH. A mesma tendência foi observada com menos eficiência em todos os outros antioxidantes lipofílicos como o BHT e BHA. Os resultados do estudo de modelagem molecular demonstraram que as propriedades eletrônicas obtidas podem ser correlacionadas com a atividade antioxidante em solução, sendo útil para o desenvolvimento racional de formulações farmacêuticas líquidas, mas não para formulações sólidas orais. Este estudo demonstrou a importância de considerar parâmetros de estabilidade e modelagem molecular para elucidar os fenômenos químicos envolvidos na atividade antioxidante, sendo úteis para o uso racional de antioxidantes no desenvolvimento de formulações farmacêuticas.

Unitermos: Antioxidantes/uso racional. Excipientes/avaliação. Hidroxianisol butilado/uso racional. Hidroxitolueno butilado/uso racional. Metabissulfito sódico/uso racional. Galato de propila/uso racional. Cisteína/uso racional. Sinvastatina/comprimidos/avaliação. Cetoconazol/comprimidos/avaliação.

\section{INTRODUCTION}

Excipients play a vital role in maintaining the expected pharmacological effect, modifying drug release rate and stability. More recently, they cannot be classified simply as diluents but also as a means of increasing weight, consistency and volume, and may even promote fast disintegration, dissolution and particularly stability (Pifferi, Restani, 2003).

The stage of formulation development in early pre-formulation studies assessing physical and chemical interactions, such as incompatibilities between an active pharmaceutical ingredient (API) and excipients of interest, has become relevant (Peres-Filho et al., 2011). Such incompatibilities may affect drug stability and bioavailability, interfering with efficacy and safety (Rowland, Tozer, 2009). A satisfactory formulation should involve careful selection of excipients, taking into account that supposedly "inert" substances often interact with APIs (Peres-Filho et al., 2011).

The efficacy, safety and stability of drugs administered in solid oral dosage forms are closely correlated with stability, as well as with solubility and permeability problems (Kommanaboyina, Rhodes, 1999; Murthy, GhebreSellassie, 1993). Physical factors such as light, heat and humidity can trigger or accelerate undesirable chemical reactions such as oxidation, hydrolysis, decarboxylation, racemization and photolysis, compromising drug stability. Oxidation rate is influenced directly by factors such as temperature, radiation and $\mathrm{pH}$ (Vadas, 2004).

A number of excipients are currently used in oral solid technology, most notably those aimed at modulating the stability of APIs. Antioxidants are introduced to improve the shelf life of pharmaceuticals. The term oxidation can be defined as the incorporation of oxygen into the structure of a drug, or as the process of converting one chemical substance into another derivative bearing a smaller number of electrons (Smith, March, 2007).

Currently, antioxidants act as efficient excipients that delay or inhibit the oxidation of organic and inorganic molecules, preventing the onset and propagation of these reactions. This effect however, depends on whether their oxidation potentials are higher than those of the other components in the formulation (Gülçin et al., 2010). Some of the most widely used antioxidants in pharmaceutical products and/or the food industry include cysteine (CYS) (Kartal et al., 2007), sodium metabisulfite (SMB) (Maia et al., 2007), propyl gallate (PG) (Chilson et al., 1950), butylated hydroxytoluene (BHT) (Williams et al., 1999) and butylated hydroxyanisole (BHA) (Perrin, Meyer, 2002).

These last three antioxidants are polyhydric phenols or derivatives, which exert antioxidant activity by supplying electrons or protons labile to free radicals that interrupt chain reactions (Wells, 2005). The others listed act by undergoing preferential oxidation because of their redox potential formulation (Gülçin et al., 2010). Several studies have suggested a correlation between the structure and activity of antioxidants. However, these reports are restricted to phenolic compounds according to the number of hydroxyl groups, their position in the molecule and redox potential (Rosch et al., 2003).

Although widely used as an antioxidant in the pharmaceutical and food industries, these excipients are associated with numerous adverse reactions such as gastric irritation, tumors and more frequently, as a cause of colic and diarrhea (Hirose et al., 1997; Okubo et al., 2004; Williams, Iatropoulos, Whysner, 1999; Williams, Iatropoulos, 2004).

Many methods for determining the antioxidant efficiency of excipients in solution have been published. These methods include the Trolox equivalent antioxidant activity assay (TEAC assay), the oxygen radical absorbance capacity assay (ORAC assay), and the 2,2-diphenyl-1-picrylhydrazyl assay (DPPH radical assay) (Cao, Sofic, Prior, 1997; Frankel, Meyer, 2000; Rice-Evans, Miller, Paganga, 1996; Sanchez-Moreno, Larrauri, Saura-Calixto, 1998). The 
DPPH method is a widely used test because it is simple, fast and reproducible (Frankel, Meyer, 2000; Rosch et al., 2003).

One approach used in the present study to evaluate the efficiency of antioxidant substances was the DPPH test (Rufino et al., 2007). This study was conducted to assess the rational use of BHA, BHT, SMB, PG and CYS in tablet formulations of simvastatin (Srinivasu, Raju, Reddy, 2002) (Figure 1) - widely used in hyperlipidemia treatment - and of ketoconazole (Figure 2) - an imidazole derivative used in the treatment of fungal infections (Viçosa et $a l ., 2009)$. These antioxidants were evaluated according to stability parameters and the relationship between the efficiency of the antioxidant and chemical structure of the drugs. Moreover, the results obtained were compared with those of DPPH tests conducted on the same excipient concentrations and computational simulations in order to achieve more rational use of this class of substances.

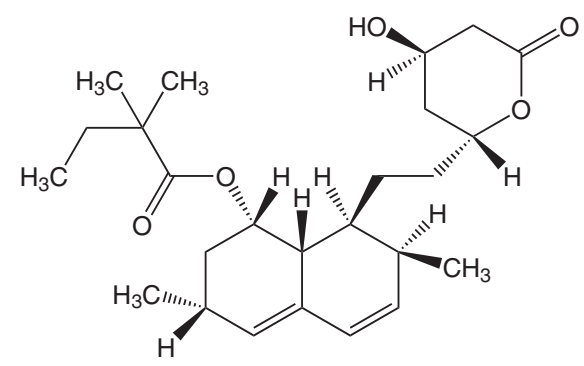

FIGURE 1 - Chemical structure of simvastatin.

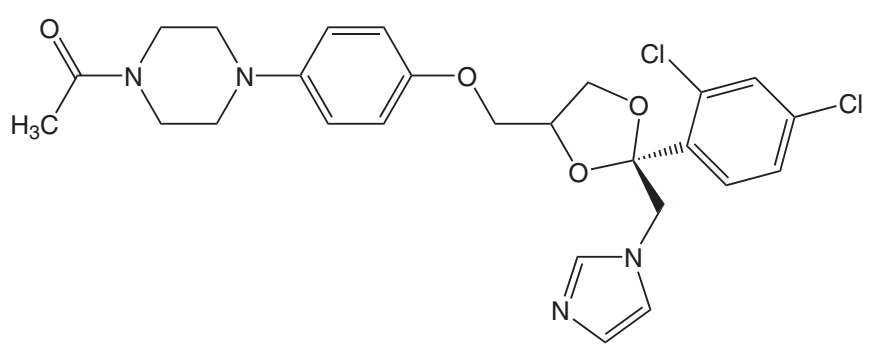

FIGURE 2 - Chemical structure of ketoconazole.

Stability studies can guide the search for solutions that minimize or delay the processes of degradation. Therefore, the ability to predict oxidation reactions in different drugs becomes extremely important.

Establishing a correlation among antioxidant activity on tests in solution, computer simulations and via concomitant application of these excipients in solid oral formulations, would represent a valuable tool for predicting the efficiency of the class of antioxidants and for rationalizing use in the technology of pharmaceutical formulations.

Thus, the aim of this work was to perform a study investigating different antioxidants' activity in solution using the DPPH test, computer simulations, and in solid oral formulations with different drugs by conducting stability studies in a bid to rationalize their use in different formulations. This correlation method is a novel approach introduced by the present manuscript.

\section{MATERIAL AND METHODS}

\section{Chemicals and solutions}

Glacial acetic acid, sodium lauryl sulfate and potassium phosphate monobasic were purchased from Merck (Merck \& Co., Darmstadt, Germany). The antioxidants (BHA, BHT, SMB, PG and CYS) were obtained from Sigma-Aldrich ${ }^{\circledR}$ (Sigma-Aldrich Corporation St. Louis, United States). Microcrystalline cellulose PH 102 (Avicel $^{\circledR}$ $\mathrm{PF}-102)$ and croscarmellose sodium $\left(\right.$ Acdisol $\left.^{\circledR}\right)$ were purchased from FMC Biopolymer (Philadelphia, USA). Colloidal silicon dioxide, magnesium stearate and spray dried monohydrate lactose were supplied by Wyndale ${ }^{\circledR}$ (Hawera, NZ). Simvastatin and ketoconazole were provided by Sigma-Aldrich ${ }^{\circledR}$ (Sigma-Aldrich Corporation St. Louis, United States). Drug standards (simvastatin and ketoconazole) were obtained from the USP 34 monograph general chapter (USP, 2011). All other chemicals were of analytical grade.

\section{Tablet production}

The quality of all raw materials used in tablet production was determined using the USP 34 monograph general chapter (USP, 2011). Cylindrical simvastatin tablets (S1 and S2) based on the Zocor $^{\circledR}$ formulation containing BHT (as described in Table I) were produced by direct compression using a punch tableting machine (Erweka, Heusenstamm, Germany). Tablets based on the S2 formulation were then produced containing BHA, CYS, PG or SMB at a concentration of $0.9 \%$. The resulting tablets were used to demonstrate the most effective of the studied excipients. The chosen antioxidant was then used at concentrations ranging from 0.05 to $0.9 \%$. Cylindrical ketoconazole tablets (K1 and K2) were produced by direct compression using the formulation given (International Conference on Harmonization, 2003) in Table II, adding the most effective antioxidant for the simvastatin formulation and SMB (traditionally used for this drug), respectively.

\section{Tablet characterization}

\section{Physical characterization}

Tablet characterization was done in accordance 
TABLE I - Formulation of simvastatin tablets S1 and S2

\begin{tabular}{lcccc}
\hline & \multicolumn{3}{c}{$\mathrm{S} 1$} & $\mathrm{~S} 2$ \\
\cline { 2 - 5 } & $\mathrm{UQ}^{\mathrm{a}}$ & $\mathrm{P}(\%)^{\mathrm{b}}$ & $\mathrm{UQ}^{\mathrm{a}}$ & $\mathrm{P}(\%)^{\mathrm{b}}$ \\
\hline Simvastatin & 20.0 & 20.0 & 20.0 & 20.0 \\
Spray-dried monohydrate lactose & 37.4 & 37.4 & $*$ & $*$ \\
Croscarmellose sodium & 1.0 & 1.0 & 3.0 & 3.0 \\
Microcrystalline cellulose PH 102 & 39.0 & 39.0 & 74.6 & 74.6 \\
Colloidal silicon dioxide & 1.0 & 1.0 & 1.0 & 1.0 \\
BHT $^{\mathrm{c}}$ & 0.9 & 0.9 & 0.9 & 0.9 \\
Magnesium stearate & 0.7 & 0.7 & 0.5 & 0.5 \\
\hline Total & 100.0 & 100.0 & 100.0 & 100.0 \\
\hline
\end{tabular}

${ }^{\mathrm{a}}$ unitary quantity; ${ }^{\mathrm{b}}$ percentage; ${ }^{\mathrm{c}}$ butylated hydroxytoluene.

* Absent in formulation.

TABLE II - Formulation of ketoconazole tablets K1 and K2

\begin{tabular}{lcccc}
\hline & \multicolumn{2}{c}{$\mathrm{K} 1$} & \multicolumn{2}{c}{$\mathrm{K}^{\mathrm{y}}$} \\
\cline { 2 - 5 } & $\mathrm{UQ}^{\mathrm{a}}$ & $\mathrm{P}(\%)^{\mathrm{b}}$ & $\mathrm{UQ}^{\mathrm{a}}$ & $\mathrm{P}(\%)^{\mathrm{b}}$ \\
\hline Ketoconazole & 200 & 42.5 & 200 & 42.5 \\
Spray-dried monohydrate lactose & 225.0 & 47.9 & 225.0 & 47.9 \\
Croscarmellose sodium & 15 & 3.2 & 15 & 3.2 \\
Microcrystalline cellulose PH 102 & 25 & 5.3 & 25 & 5.3 \\
Colloidal silicon dioxide & 2.5 & 0.53 & 2.5 & 0.53 \\
BHT $^{\mathrm{c}}$ & 0.47 & 0.1 & $*$ & $*$ \\
SMB $^{\text {d }}$ & $*$ & $*$ & 0.47 & 0.1 \\
Magnesium stearate $^{\text {Total }}$ & 2.5 & 0.53 & 2.5 & 0.53 \\
\hline
\end{tabular}

${ }^{\mathrm{a}}$ unitary quantity; ${ }^{\mathrm{b}}$ percentage; ${ }^{\mathrm{c}}$ butylated hydroxytoluene; ${ }^{\mathrm{d}}$ sodium metabisulphite.

* Absent in formulation

with the USP 34 monograph general chapter (USP, 2011), observing sample friability (friabilometer NT 240 Nova Ética, Brazil), weight (analytical balance AG-204 Mettler Toledo, Brazil), hardness (hardness tester 298-ATTS Nova Ética, Brazil), and disintegration in water at $37^{\circ} \mathrm{C}$ (tablet disintegrator 301-AC Nova Ética, Brazil). Sample friability and hardness were calculated as the mean of ten determinations, sample weight as the mean of twenty determinations, and disintegration time as the mean of six determinations.

\section{Chemical characterization}

Content uniformity of the tablets was determined in accordance with the USP 34 monograph general chapter (USP, 2011), by UV detector (UV-Vis spectrophotometer L-4250, Shimadzu Co.Ltd., Kyoto, Japan) set at $238 \mathrm{~nm}$ for simvastatin, and $225 \mathrm{~nm}$ for ketoconazole.

\section{Simvastatin content}

The content was as described in the USP 34 monograph for simvastatin tablets (USP, 2011). Chromatographic separations were carried out with a $\mathrm{C}_{18}(4.6 \mathrm{~mm} \mathrm{x}$ $25 \mathrm{~cm}$ ) column containing L1 packing, using acetonitrile and a phosphoric buffer solution with pH 4.5 (65:35) as the mobile phase. Injection volumes were $10 \mu \mathrm{L}$ for all simvastatin tablet samples at a flow rate of $1.5 \mathrm{~mL} \cdot \mathrm{min}^{-1}$ at $45^{\circ} \mathrm{C}$. The UV detector was set at $238 \mathrm{~nm}$. Sample and standard solutions were prepared using an acetic acid 3.0\% aqueous solution with $\mathrm{pH} 4.0$ : acetonitrile (20:80).

\section{Ketoconazole content}

The content test was performed as described in the USP 34 monograph for ketoconazole tablets (USP, 2011). Analyses were carried out with a $\mathrm{C}_{18}(3.9 \mathrm{~mm} \times 30 \mathrm{~cm}) \mathrm{col}-$ umn containing L1 packing, using a mixture of diisopro- 
pylamine in methanol ( 1 in 500) and ammonium acetate solution (1 in 200) (70:30) as the mobile phase. Injection volumes were $20 \mu \mathrm{L}$ with a flow rate of $2.0 \mathrm{~mL} \cdot \mathrm{min}^{-1}$ at room temperature. The UV detector was set at $225 \mathrm{~nm}$. The samples and standard were diluted using a mixture of methanol and methylene chloride (50:50).

\section{Dissolution study}

\section{Simvastatin tablet dissolution}

Dissolution studies of simvastatin tablets were performed using the rotating-paddle method (Hanson Research, SR8 8-Flask Bath, Ontario, Canada) for 30 minutes, at $50 \mathrm{rpm}$. A volume of $900 \mathrm{~mL}$ of dissolution medium was used, which consisted of sodium phosphate buffer $0.01 \mathrm{M} \mathrm{pH} 7.0$ containing $0.5 \%$ sodium dodecyl sulfate according to the procedure described in the USP 34 monograph for this tablet (USP, 2011). After 30 minutes, the aliquot was filtered through a $0.45 \mu \mathrm{m}$ filter and transferred to a centrifuge tube containing approximately $10 \mathrm{mg}$ of prewashed manganese dioxide per $1 \mathrm{~mL}$ of transferred solution under test. These mixtures were maintained under stirring for 30 minutes and centrifuged. Samples, standard and blank absorbance were then measured at $238 \mathrm{~nm}$ in a spectrophotometer (UV-Vis spectrophotometer L-4250, Shimadzu Co.Ltd., Kyoto, Japan).

\section{Ketoconazole tablet dissolution}

Dissolution studies of ketoconazole tablets were performed using the rotating-paddle method, according to the procedure described in the USP 34 monograph for this tablet (USP, 2011). Dissolution was carried out for 30 minutes at $50 \mathrm{rpm}$ with $900 \mathrm{~mL}$ of $0.1 \mathrm{~N}$ hydrochloric acid. After 30 minutes, samples were filtered through a $0.45 \mu \mathrm{m}$ filter and diluted with dissolution medium. Samples, standard and blank absorbance were then measured at $225 \mathrm{~nm}$ in a spectrophotometer (UV-Vis spectrophotometer L-4250, Shimadzu Co.Ltd., Kyoto, Japan).

\section{Stability study}

The accelerated stability study of all the tablet formulations produced was performed at $40^{\circ} \mathrm{C} \pm 2^{\circ} \mathrm{C}$ and $75 \% \pm 5 \%$ relative humidity, at sampling times of 0 , 3 and 6 months (Brasil, 2005), denoted T0, T1 and T2, respectively (stability chambers, 420/CLD Nova Ética, São Paulo, Brazil). Content and dissolution studies were conducted at each timepoint.

\section{DPPH antioxidant activity assay}

Determination of the antioxidant capacity of the studied excipients was performed using an adapted DPPH method (Rufino et al., 2007). Initially, stock solutions of methanol:water (50:50), acetone:water (70:30) were prepared, as well as a control solution of methanol and acetone stock solutions mixed with water (40:40:20). A $0.06 \mathrm{mM}$ DPPH radical standard solution was prepared in methanol for the analysis of BHA, BHT, CYS and PG, and in distilled water for analysis of SMB. The sample solutions $(1.0 \mathrm{mg} / \mathrm{mL})$ were prepared in methanol or distilled water, respectively. A $3.9 \mathrm{~mL}$ volume of the standard solution, $0.1 \mathrm{~mL}$ of the sample solution and $0.1 \mathrm{~mL}$ of the control solution, were added to an assay tube. Methanol or water was used as a blank. The reaction was performed in the dark at room temperature, and the analyses were conducted using a spectrophotometer measuring absorbance reduction at $515 \mathrm{~nm}$. The DPPH calibration curve was prepared using the initial standard solution at concentrations ranging from 10 to $60 \mathrm{mM}$.

\section{Molecular modeling studies}

Molecular modeling was performed using SPARTAN'09 software (Wavefunction Inc. Irvine, CA, 2000. Using this software, structures were minimized and the equilibrium geometry obtained in a vacuum using a semi-empirical AM1 module (Rocha et al., 2006). In order to evaluate the electronic properties of the AM1 minimal energy conformations, they were submitted to a single-point calculation using the density functional theory (DFT) method, B3LYP functional and the 6-31G* basis set of SPARTAN'09. The electronic properties including HOMO (Highest Occupied Molecular Orbital) and LUMO (Lowest Unoccupied Molecular Orbital) energies and density, coefficient distribution, GAP (difference between HOMO and LUMO orbitals), absolute hardness $(\eta$, correlated to the amount of energy needed for the transition of an electron from the HOMO to the LUMO orbitals) (Arroio, Honório, Silva, 2010) and dipole moment vector, were calculated for all compounds. Molecular electrostatic potential isoenergy surface maps were also generated with a range of energies from - 25 (deepest red) to 30 (deepest blue) $\mathrm{kcal} / \mathrm{mol}$ and superimposed onto a surface having a constant electron density of $0.002 \mathrm{e} / \mathrm{au} 3$.

\section{RESULTS AND DISCUSSION}

\section{Tablet production and characterization}

The raw materials were analyzed, yielding $99.40 \%$ content for simvastatin without the presence of lovastatin, considered an impurity, and $98.15 \%$ for ketoconazole (Bertacche et al., 2007; Markman, Rosa, Koschtschak, 


\section{0).}

The proposed formulations of the tablets were produced (S1 and S2) based on the Zocor ${ }^{\circledR}$ formulation, showing difference in the presence of lactose in $\mathrm{S} 1$ (as in Zocor $^{\circledR}$ formulation) and increased croscarmellose sodium and microcrystalline cellulose PH 102 concentrations in S2, with lactose removal. The ketoconazole tablets were produced using a previous formulation developed by our research group (Viçosa et al., 2009).

Sample weight, friability, hardness, disintegration, dissolution and content uniformity for all the simvastatin and ketoconazole tablets produced (data not shown) were in accordance with the USP 34 monograph general chapter (USP, 2011).

For the simvastatin tablets, the characterization tests demonstrated that the absence of lactose allowed for higher flux, lower adherence to the top punches of the compressor machine and greater reproducibility of results for hardness and sample weight, resulting in differences between formulations. Also, the increased proportion of croscarmellose sodium, a disintegrant excipient, in the S2 formulation from 1.0 to $3.0 \%$ contributed to increased disintegration of the tablet and release of the API, as expected. Initially, the improvement in the dissolution rate of the S2 formulation compared to $\mathrm{S} 1$ was around $6 \%(\mathrm{p}=0.0038)$.

The improvement in dissolution rate of the $\mathrm{S} 2$ formulation compared to $\mathrm{S} 1$ could be attributed to the use of a soluble solvent possessing reducing properties (Pifferi, Santoro, Pedrani, 1999). The addition of a larger proportion of directly compressed microcrystalline cellulose $\mathrm{PH}$ 102 may lead to more efficient disintegration, enhancing the dissolution of the active simvastatin (Shirzad, Roa, Raimar, 2007).

After the production of S1 and S2 formulations, the dissolution profile and the tableting process were used as factors for selecting the optimal formulation. Therefore,
S2 was considered more technically favorable than S1 for tablet production. However, since lactose was used, this behavior would not normally be expected, specifically for the direct compression processes (lactose $\alpha$-spray dryer) (Prista, Alves, Morgado, 2002). This suggests a possible interaction between simvastatin and lactose. The use of lactose as an excipient for direct compression can sometimes result in drug - excipient incompatibility, as observed in the Maillard reaction (Bharate, Bharate, Bajaj, 2010). Apart from the lactose factor, greater croscarmellose sodium in the formulation was observed, which also contributed to the disintegration of the tablet and release of the active ingredient.

The S2 formulation was considered more appropriate and therefore used as a prototype for the others to be studied. The ketoconazole tablets were produced without any technical problems.

\section{DPPH antioxidant activity assay}

The antioxidant activity of the selected excipients (BHA, BHT, SMB, PG and CYS) was evaluated by a method adapted from DPPH (Rufino et al., 2007). The DPPH calibration curve obtained was linear with a correlation coefficient of 0.9977 . The analysis shown in Table III reveals that the largest percentage reduction of absorbance was observed for PG, while SMB proved to be most efficient, with only $6.47 \%$ reduction and lower consumption of DPPH.

The same pattern was observed, albeit with lower efficiency, for all the other lipophilic antioxidants such as BHT and BHA, indicating a relationship between solvation effect and efficacy of the excipient. This indicates that the greater polarizability of the molecule showed higher electronic stabilization and solvation effects during its transition state, resulting in higher efficiency in solution.

TABLE III - Comparative evaluation of antioxidant activity with DPPH

\begin{tabular}{lcccccc}
\hline Antioxidant & $\begin{array}{c}\text { Initial } \\
\text { absorbance } \pm \\
\text { r.s.d.* }\end{array}$ & $\begin{array}{c}\text { Final } \\
\text { absorbance } \\
\text { r.s.d.* }\end{array}$ & $\begin{array}{c}\text { Control } \\
\text { absorbance }\end{array}$ & $\begin{array}{c}\text { Relative } \\
\text { percentage of } \\
\text { absorbance } \\
\text { reduction }\end{array}$ & Solvent & $\begin{array}{c}\text { Time for } \\
\text { stabilization } \\
(\mathrm{min})\end{array}$ \\
\hline $\mathrm{CYS}^{\mathrm{a}}$ & $0.642 \pm 0.046$ & $0.275 \pm 0.017$ & 0.701 & 57.16 & methanol & 120 \\
PG $^{\mathrm{b}}$ & $0.383 \pm 0.082$ & $0.004 \pm 0.00013$ & 0.702 & 98.95 & methanol & 2 \\
SMB $^{\mathrm{c}}$ & $0.603 \pm 0.035$ & $0.564 \pm 0.070$ & 0.701 & 6.47 & water & 60 \\
BHA $^{\mathrm{d}}$ & $0.570 \pm 0.028$ & $0.119 \pm 0.009$ & 0.701 & 79.12 & methanol & 60 \\
BHT $^{\mathrm{e}}$ & $0.606 \pm 0.022$ & $0.139 \pm 0.0071$ & 0.701 & 77.06 & methanol & 160 \\
\hline
\end{tabular}

${ }^{\mathrm{a}}$ cysteine; ${ }^{\mathrm{b}}$ propyl gallate; ${ }^{\mathrm{c}}$ sodium metabisulfite; ${ }^{\mathrm{d}}$ butylated hydroxyanisole; ${ }^{\mathrm{e}}$ butylated hydroxytoluene.

* relative standard deviation. 
These results raise the question as to whether the same holds true for the solid phase (Barclay et al., 1990).

\section{Stability study}

During the stability study, it is important to verify both drug content and dissolution rate at all sampling times because the drug can degrade, for example by oxidation, reducing the content, while degradation products can influence dissolution rate (International Conference on Harmonization, 2003; Brasil, 2005).

The antioxidants BHA, BHT, CYS, PG or SMB were included in the $\mathrm{S} 2$ formulation at $0.9 \%$ to determine which was most efficient in terms of drug stability and the most efficient solid phase antioxidant. According to the results obtained in the accelerated stability study of these formulations (Table IV), BHT was the most efficient regarding simvastatin stability, exhibiting around $10 \%$ content variation. The content of the formulations with PG, BHA, CYS and SMB had variations of approximately $11.6,11.1,31.7$ and $21.7 \%$, respectively. In contrast to the behavior observed in solution, CYS and SMB were the least efficient in solid phase among all antioxidants studied. BHA and PG proved to be statistically similar in terms of content maintenance $(p=0.0789)$.

Due to its efficiency in controlling the content of this drug, in comparison with other antioxidants, the other formulations were produced using BHT at concentrations of $0.05,0.1,0.5$ and $0.9 \%$ (Table V). The most effective concentrations of BHT in terms of lowest content, dissolution variations, and maintaining the stability of simvastatin, were 0.5 and $0.1 \%$. Thus, the lowest concentration was chosen as optimal for the case of simvastatin, avoiding side effects and reducing costs. The extreme values of $0.05 \%$ and $0.9 \%$ were less efficient in terms of maintaining the content and dissolution of pharmacotechnical ingredients. All results differed statistically in terms of the content of simvastatin $(\mathrm{p}=0.0032)$ and dissolution $(\mathrm{p}=0.0023)$.

$\mathrm{S} 2$ is an uncoated tablet and highly stable when BHT $0.1 \%$ was used, proving that a coating is not essential for maintaining drug stability of simvastatin formulations. Zocor $^{\circledR}$ is a coated tablet which has a higher antioxidant concentration than $\mathrm{S} 2$, making this reference drug more susceptible to the occurrence of side effects with an inherently more expensive manufacturing process (Hirose et al., 1997; Okubo et al., 2004; Williams, Iatropoulos, Whysner, 1999; Williams, Iatropoulos, 2004).

The inefficiency of SMB in the S2 formulation is in contrast to that described in the literature for this excipient (Lavoie, Lachance, Chessex, 1994) and to the DPPH assay results. A possible explanation may lie in the chemical structure of the molecule, which acts to prevent degradation, or in the oxidation mechanism involved. In the case of SMB, capture and stabilization of free radicals was not always observed as for BHA or BHT (Brand-Williams, Cuvelier, Berset, 1995).

Initially, the mechanism of oxidation of simvastatin involves capturing these radical forms, which leads to greater efficiency for BHT (Mohamadin et al., 2011). However, this hypothesis can only be confirmed by replacing the studied drug. Therefore, in order to elucidate the above-mentioned relationship, two different ketoconazole tablet formulations were produced ( $\mathrm{K} 1$ and $\mathrm{K} 2$ ).

$\mathrm{SMB}$, previously used for the production of ketoconazole tablets (Viçosa et al., 2009) was used at $0.1 \%$ in

TABLE IV - Stability study of S2 formulation with different antioxidants

\begin{tabular}{lllll}
\hline & & T0 & T1 & T2 \\
\hline BHT $^{\mathrm{a}}$ 0.9\% & Content (\%) \pm r.s.d. & $98.2 \pm 1.6$ & $89.3 \pm 2.4$ & $88.2 \pm 0.9$ \\
& Dissolution (\%) \pm r.s.d. & $86.2 \pm 3.8$ & $82.0 \pm 5.1$ & $77.4 \pm 5.0$ \\
PG $^{\mathrm{b}}$ 0.9\% & Content (\%) \pm r.s.d. & $92.2 \pm 1.3$ & $88.6 \pm 2.5$ & $80.6 \pm 1.2$ \\
& Dissolution (\%) \pm r.s.d. & $82.5 \pm 5.4$ & $77.5 \pm 5.0$ & $72.4 \pm 6.9$ \\
BHA $^{\mathrm{c}}$ 0.9\% & Content (\%) \pm r.s.d. & $94.3 \pm 0.4$ & $89.2 \pm 3.0$ & $83.2 \pm 1.8$ \\
& Dissolution (\%) \pm r.s.d. & $82.6 \pm 4.9$ & $75.3 \pm 5.3$ & $70.0 \pm 5.1$ \\
CYS $^{\text {d }}$ 0.9\% & Content (\%) \pm r.s.d. & $95.2 \pm 1.4$ & $86.8 \pm 1.1$ & $63.5 \pm 3.2$ \\
& Dissolution (\%) \pm r.s.d. & $83.2 \pm 6.0$ & $79.8 \pm 5.2$ & $54.8 \pm 7.0$ \\
SMB $^{\text {e }}$ 0.9\% & Content (\%) \pm r.s.d. & $93.5 \pm 1.2$ & $81.4 \pm 2.2$ & $71.8 \pm 1.2$ \\
& Dissolution (\%) \pm r.s.d. & $84.4 \pm 3.6$ & $72.3 \pm 4.5$ & $68.3 \pm 4.3$ \\
\hline
\end{tabular}

${ }^{\mathrm{a}}$ butylated hydroxytoluene; ${ }^{\mathrm{b}}$ propyl gallate; ${ }^{\mathrm{c}}$ butylated hydroxyanisole; ${ }^{\mathrm{d}}$ cysteine; ${ }^{\mathrm{e}}$ sodium metabisulfite.

* relative standard deviation. 
TABLE V - Stability study of S2 formulation containing BHT as antioxidant at different concentrations

\begin{tabular}{lllll}
\hline & & T0 & T1 & T2 \\
\hline BHT $^{a}$ 0.9\% & Content (\%) \pm r.s.d. & $98.2 \pm 1.6$ & $89.3 \pm 2.4$ & $88.2 \pm 0.9$ \\
& Dissolution (\%) \pm r.s.d. & $86.2 \pm 3.8$ & $82.0 \pm 5.1$ & $77.4 \pm 5.0$ \\
BHT 0.5\% & Content (\%) \pm r.s.d. & $93.5 \pm 0.6$ & $90.9 \pm 0.5$ & $88.2 \pm 1.2$ \\
& Dissolution (\%) \pm r.s.d. ${ }^{*}$ & $87.4 \pm 3.4$ & $83.0 \pm 2.8$ & $79.2 \pm 5.0$ \\
BHT 0.1\% & Content (\%) \pm r.s.d. & $94.6 \pm 0.5$ & $91,3 \pm 0.3$ & $89.3 \pm 2.0$ \\
& Dissolution (\%) \pm r.s.d. & $85.2 \pm 2.4$ & $82.0 \pm 4.5$ & $77.4 \pm 5.5$ \\
BHT 0.05\% & Content (\%) \pm r.s.d. & $95.9 \pm 0.2$ & $92.9 \pm 0.6$ & $85.6 \pm 1.2$ \\
& Dissolution (\%) \pm r.s.d. & $85.4 \pm 4.7$ & $81.0 \pm 4.0$ & $78.7 \pm 3.6$ \\
\hline
\end{tabular}

${ }^{\mathrm{a}}$ butylated hydroxytoluene.

* relative standard deviation.

this study; the rationalized concentration in previous tests with simvastatin.

Two different ketoconazole tablet formulations were produced (K1 and $\mathrm{K} 2$ ). The results of accelerated stability studies for these tablets are given in Table VI. According to the results, SMB was most efficient at maintaining the content and dissolution profile for this drug.

A strong relationship between drug structure and antioxidant efficiency was observed. This relationship was evidenced by the stability studies of ketoconazole tablets, where BHT, the most efficient antioxidant for simvastatin tablets, presented a higher variation in content between the start and end of the test when compared to SMB. The dissolution values changed only slightly over a six-month period for both formulations, remaining above the $80 \%$ required by the USP 34 monograph general chapter (USP, 2011).

\section{Molecular modeling studies}

Several molecular electronic parameters were calculated for the antioxidants BHA, BHT, CYS, SMB and PG (dipole moment, cLogP and energy of HOMO and LUMO orbitals) and compared with antioxidant activity. Overall, no clear or direct correlation was observed for most of the parameters evaluated except for the orbitals HOMO and
LUMO and for the analysis of the 3-D structures. (Figure 3 and Table VII). Higher values of $\mathrm{E}_{\text {номо }}$ were observed for SMB, BHA, BHT, PG and CYS indicating a better antioxidant profile for SMB, BHA and BHT, supporting the results of studies in solid phase (tablet stability).

The effects of hydrogen bonds between methanol or other polar protic solvent and phenolic antioxidants can also lead to a reduction in their activity (Ghose, Pritchett, Crippen, 1988). In this initial evaluation, CYS and SMB were chosen as the most effective antioxidants. These results were confirmed by the values of cLogP calculated by molecular modeling using the method of Ghose-PritchettCrippen (Ghose, Pritchett, Crippen, 1988) showing the influence of lipid solubility on antioxidant activity.

Moreover, the values of GAP and absolute hardness were in agreement with the results obtained on the DPPH assay, demonstrating that antioxidant activity is directly related to the hardness and softness of each compound when in solution. Thus, the lower GAP value led to greater reactivity of the molecule in solution for the radical capturing reaction. Also, the lower the hardness, the lower the amount of energy needed for the transition of an electron from HOMO to LUMO. In this case, the molecule with the highest antioxidant activity in the DPPH assay was SMB $(\eta=-1.72$ and $\mathrm{GAP}=-3.44)$.

TABLE VI - Stability study of K1 and K2 tablet formulations

\begin{tabular}{lllll}
\hline & & T0 & T1 & T2 \\
\hline BHT $^{\mathrm{a}}$ 0.1\% & Content (\%) \pm r.s.d. & $98.1 \pm 0.3$ & $83.6 \pm 0.3$ & $69.7 \pm 1.5$ \\
& Dissolution (\%) \pm r.s.d. & $89.0 \pm 3.2$ & $83.5 \pm 3.7$ & $83.9 \pm 4.6$ \\
SMB $^{\text {b }}$ 0.1\% & Content (\%) \pm r.s.d. & $99.7 \pm 0.5$ & $98.5 \pm 1.2$ & $97.7 \pm 1.9$ \\
& Dissolution (\%) \pm r.s.d. & $88.3 \pm 4.5$ & $86.4 \pm 3.7$ & $85.9 \pm 3.5$ \\
\hline
\end{tabular}

${ }^{\mathrm{a}}$ butylated hydroxytoluene; ${ }^{\mathrm{b}}$ sodium metabisulfite.

* relative standard deviation. 
TABLE VII - Theoretical properties of tested antioxidants

\begin{tabular}{lccccc}
\hline ANTIOXIDANT & $\mathrm{E}_{\text {номо }}{ }^{\mathrm{a}}$ & $\mathrm{E}_{\text {LUMO }}{ }^{\mathrm{b}}$ & $\mathrm{GAP}(\mathrm{H}-\mathrm{L})^{\mathrm{c}}$ & $\eta^{\mathrm{d}}$ & $\operatorname{cLogP}^{\mathrm{e}}$ \\
\hline BHT $^{\mathrm{f}}$ & -5.73 & 0.26 & -5.99 & -2.99 & 5.54 \\
BHA $^{\mathrm{g}}$ & -5.12 & 0.18 & -5.30 & -2.65 & 3.22 \\
$\mathrm{CYS}^{\mathrm{h}}$ & -6.31 & -0.18 & -6.13 & -3.06 & -0.92 \\
PG $^{\mathrm{i}}$ & -5.88 & -0.89 & -4.99 & -2.49 & 1.51 \\
$\mathrm{SMB}^{\mathrm{j}}$ & -3.39 & 0.13 & -3.44 & -1.72 & -1.35 \\
\hline
\end{tabular}

${ }^{\mathrm{a}} \mathrm{HOMO}$ energy; ${ }^{\mathrm{b}} \mathrm{LUMO}$ energy; ${ }^{\mathrm{c}} \mathrm{Gap}$ : difference between HOMO and LUMO orbitals; ${ }^{\mathrm{d}}$ absolute hardness; ${ }^{\mathrm{e}}$ partition coefficient calculated by the Ghose-Pritchett-Crippen method; ${ }^{\mathrm{f}}$ butylated hydroxytoluene ${ }^{\mathrm{g}}$ butylated hydroxyanisole; ${ }^{\mathrm{h}}$ cysteine; ${ }^{\mathrm{i}}$ propyl gallate; ${ }^{j}$ sodium metabisulfite.

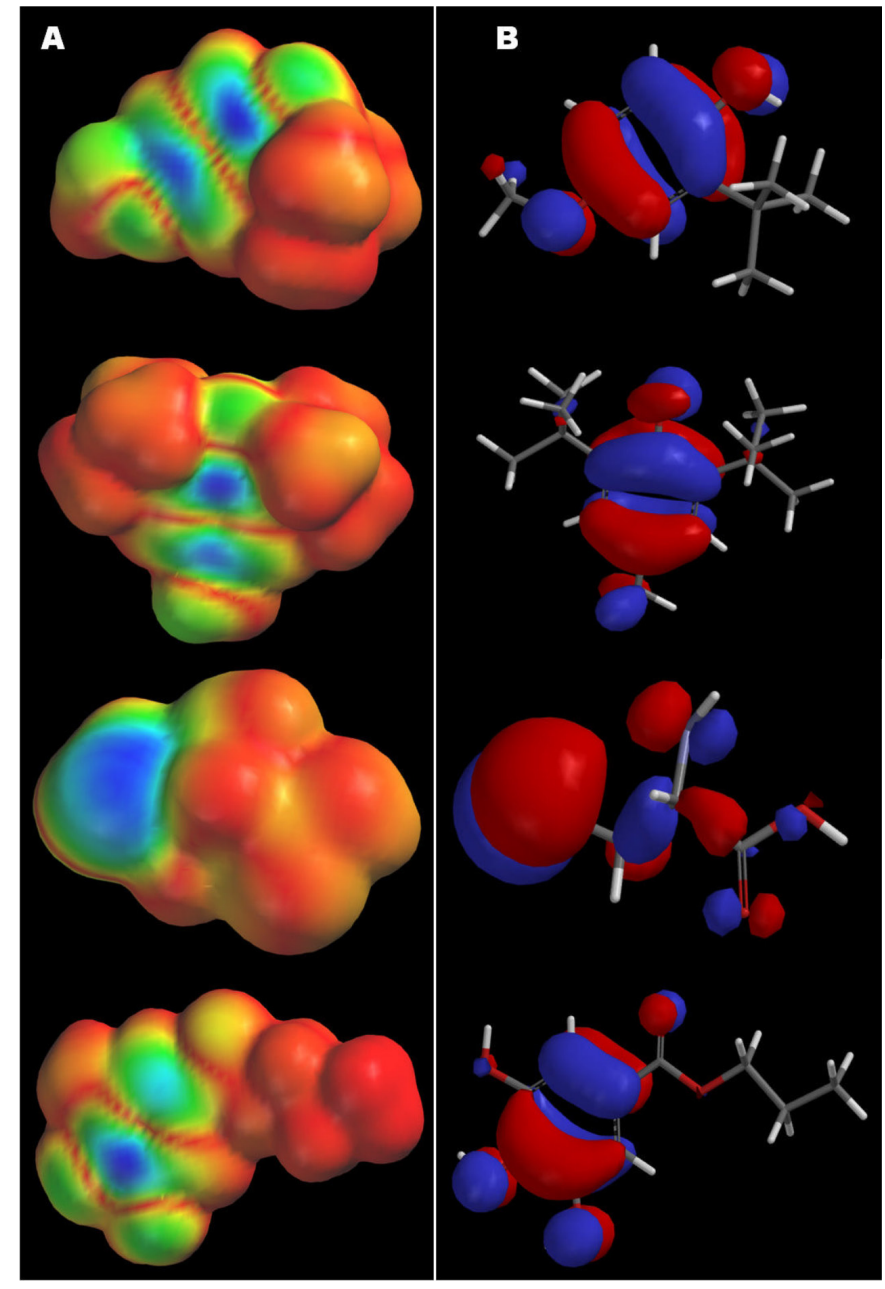

FIGURE 3 - 3D representation for antioxidants BHA, BHT, CYS and $\mathrm{PG}$ respectively. $\mathrm{HOMO}(\mathrm{A})$ densities encoded onto a van der Waals surface (isodensity $0.002 \mathrm{e} / \mathrm{au}^{3}$ ), the orbital absolute density HOMO coefficient (B) was mapped from deepest red $(0.00)$ to deepest blue $(0.01)$.

The results of this study showed that theoretical parameters obtained by molecular modeling were correlated with antioxidant activity in solution, being useful for the rational development of liquid pharmaceutical formula- tions but not for solid oral formulations.

\section{CONCLUSIONS}

In conclusion, the results of the present study showed that it is not possible to rationalize the use of antioxidants in solid formulations. The results revealed inefficiency of SMB in the S2 formulation, in contrast to behavior described in the literature for this excipient.

However, the use of antioxidants in solution (DPPH and molecular modeling) were in agreement, showing a rational correlation with antioxidant activity in solution, being a useful tool for the rational development of liquid pharmaceutical formulations.

In addition, the use of different excipients in the formulation of tablets influences both functionality and choice of antioxidants.

\section{ACKNOWLEDGMENTS}

This research was supported by the Coordenação de Aperfeiçoamento de Pessoal de Nível Superior (CAPES Nanobiotec 2008); Conselho Nacional de Desenvolvimento Científico e Tecnológico (CNPq) and Fundação de Amparo à Pesquisa do Estado do Rio de Janeiro Carlos Chagas Filho (FAPERJ).

\section{REFERENCES}

ARROIO, A.; HONÓRIO, K.M.; SILVA, A.B.F. Propriedades químico-quânticas empregadas em estudos das relações estrutura-atividade. Quim. Nova, v.33, p.694-699, 2010.

BARCLAY, L.R.C.; BASKIN, K.A.; DAKIN, K.A.; LOCKE, S.J.; VINQVIST, M.R. The antioxidant activities in 9 free radical peroxidation of phospholipid membranes. Can. J. Chem., v.68, p.2258-2269, 1990. 
BERTACCHE, V.; MILANESE, A.; NAVA, D.; PINI, E.; STRADI, R. Structural elucidation of an unknown simvastatin by-product in industrial synthesis starting from Lovastatin. J. Pharm. Biomed. Anal., v.45, p.642-647, 2007.

BHARATE, S.S.; BHARATE, S.B.; BAJAJ, A.N. Interactions and incompatibilities of pharmaceutical excipients with active pharmaceutical ingredients: a comprehensive review. J. Excip. Food Chem., v.1, p.3-26, 2010.

BRAND-WILLIAMS, W.; CUVELIER, M.E.; BERSET, C. Use of a free radical method to evaluate antioxidant activity. Lebensm.-Wiss. Technol., v.28, p.25-30, 1995.

BRASIL. Ministério da Saúde. Agência Nacional de Vigilância Sanitária. Resolução RE nº1, de 29 de julho de 2005. Guia para a realização de estudos de estabilidade. Diário Oficial da União. Brasília, 01 ago. 2005. p.119, seção 1.

CAO, G.; SOFIC, E.; PRIOR, R.L. Antioxidant and prooxidant behavior of flavonoids: structure-activity relationship. Free Radical Biol. Med., v.22, p.749-760, 1997.

CHILSON, W.H.; MARTIN, W.H.; WHITNAH, C.H. Use of propyl gallate to defer development of oxidized flavor in market milk. J. Dairy Sci., v.33, p.925-928, 1950.

FRANKEL, E.N.; MEYER, A.S. The problems of using one dimensional methods to evaluate multifunctional food and biological antioxidants. J. Sci. Food Agric., v.80, p.19251941, 2000.

GHOSE, A.K.; PRITCHETT, A.; CRIPPEN, G.M. Atomic physicochemical parameters for three dimensional structure directed quantitative structure-activity relationships III: modeling hydrophobic interactions. J. Comput. Chem., v.9, p.80-87, 1988 .

GÜLÇIN, I.; HUYUT, Z.; ELMASTAS, M.; ABOUL-ENEIN, H.Y. Radical scavenging and antioxidant activity of tannic acid. Arab. J. Chem., v.3, p.43-53, 2010.

HIROSE, M.; TAKESADA, Y.; TANAKA, H.; TAMANO, S.; KATO, T.; SHIRAI, T. Carcinogenicity of antioxidants BHA, caffeic acid, sesamol, 4-methoxyphenol and catechol at low doses, either alone or in combination, and modulation of their effects in a rat medium-term multi-organ carcinogenesis model. Carcinogenesis, v.19, p.207-212, 1997.
INTERNATIONAL CONFERENCE ON HARMONISATION. Q1A(R2): Harmonised tripartite guideline stability testing of new drug substances and products. Current step 4 version, dated 6 Feb, p. 6-13, 2003.

KARTAL, A.; BJÖRQVIST, M.; LEHTO, V-P.; MARVOLA, M.; SÄKKINEN, M. Stability and compatibility study of L-cysteine with commonly used chewing gum excipients. Eur. J. Pharm. Sci., v.S32, S22-S50, 2007.

KOMMANABOYINA, B; RHODES, C.T. Trends in stability testing, with emphasis on stability during distribution and storage. Drug Dev. Ind. Pharm., v.25, p.857-868, 1999.

LAVOIE, J.C.; LACHANCE, C.; CHESSEX, P. Antiperoxide activity of sodium metabisulfite: a double-edged sword. Biochem. Pharmacol., v.45, p.871-876, 1994.

MAIA, A.M.; BABY, A.R.; YASAKA,W.J.; SUENAGA, E.; KANEKO, T.M.; VELASCO, M.V.R. Validation of HPLC stability-indicating method for Vitamin $\mathrm{C}$ in semisolid pharmaceutical/cosmetic preparations with glutathione and sodium metabisulfite, as antioxidants. Talanta, v.71, p.639-643, 2007.

MARKMAN, B.E.O.; ROSA, P.C.P.; KOSCHTSCHAK, M.R.W. Assessment of the quality of simvastatin capsules from compounding pharmacies. Rev. Saúde Pública, v.44, p.1055-1062, 2010.

MOHAMADIN, A.M.; ELBERRY, A.A.; GAWAD, H.S.A.; MORSY, G.M.; AL-ABBASI, F.A. Protective effects of simvastatin, a lipid lowering agent, against oxidative damage in experimental diabetic rats. J. Lipids, v.2011, p.1-13, 2011.

MURTHY, K.S.; GHEBRE-SELLASSIE, I. Current perspectives on the dissolution stability of solid oral dosage forms. $J$. Pharm. Sci., v.82, p.113-126, 1993.

OKUBO, T.; YOKOYAMA, Y.; KANO, K.; KANO I. Molecular mechanism of cell death induced by the antioxidant tertbutylhydroxyanisole in human monocytic leukemia U937 cells. Biol. Pharm. Bull., v.27, p.295-302, 2004.

PERES-FILHO, M.J.; GAETTI, M.P.N.; DE OLIVEIRA, S.R.; MARRETO, R.N.; LIMA, E.M. Thermoanalytical investigation of olanzapine compatibility with excipients used in solid oral dosage forms. J. Therm. Anal. Calorim., v.104, p.256-260, 2011. 
PERRIN, C.; MEYER, L. Quantification of synthetic phenolic antioxidants in dry foods by reversed-phase HPLC with photodiode array detection. Food Chem., v.77, p.93-100, 2002.

PIFFERI, G.; SANTORO, P.; PEDRANI, M. Quality and functionality of excipients. Farmaco, v.54, p.1-14, 1999.

PIFFERI, G.; RESTANI, P. The safety of pharmaceutical excipients. Institute of Pharmaceutical and Toxicological Chemistry. Farmaco, v.58, p.541-550, 2003.

PRISTA, L.N.; ALVES, A.C.; MORGADO, R.M.R. Tecnologia farmacêutica. Lisboa: Fundação Calouste Gulbenkian, 2002. p.230-246.

RICE-EVANS, C.A.; MILLER, N.J.; PAGANGA, G. Structure antioxidant activity relationships of flavonoids and phenolic acids. Free Radical Biol. Med., v.20, p.933-956, 1996.

ROCHA, G.B.; FREIRE, R.O.; SIMAS, A.M.; STEWART, J.J.P. $\mathrm{Rm} 1$ : a reparameterization of AM1 for $\mathrm{H}, \mathrm{C}, \mathrm{N}, \mathrm{O}, \mathrm{P}, \mathrm{S}, \mathrm{F}$, Cl, Br, and I. J. Comput. Chem., v.27, p.1101-1111, 2006.

ROSCH, D.; BERGMANN, M.; KNORR, D.; KROH, L.W. Structure antioxidant efficiency relationships of phenolic compounds and their contribution to the antioxidant activity of sea buckthorn juice. J. Agric. Food Chem., v.51, p.42334239, 2003.

ROWLAND, M.; TOZER, T.N. Introdução à farmacocinética e à farmacodinâmica - as bases quantitativas da terapia farmacológica. Porto Alegre: Ed. Artmed, 2009. p.142-143.

RUFINO, M.S.M.; ALVES, R.E.; BRITO, E.S.; MORAIS, S.M.; SAMPAIO, C.G.; PÉREZ-JIMÉNEZ, J.; SAURACALIXTO, F. Metodologia científica: determinação da atividade antioxidante total em frutas pela captura do radical livre DPPH. Comunicado Técnico No 127 . Fortaleza: Embrapa, 2007. 4 p.

SANCHEZ-MORENO, C.; LARRAURI, J.A.; SAURACALIXTO, F.A procedure to measure the antiradical efficiency of polyphenols. J. Sci. Food Chem., v.76, p.270$276,1998$.
SHIRZAD, A.; ROA, W.; RAIMAR, L. Current perspectives in dissolution testing of conventional and novel dosage forms. Int. J. Pharm., v.328, p.12-21, 2007.

SMITH, M.B.; MARCH, J. Advanced organic chemistry: reactions, mechanisms, and structure. New Jersey: Ed. John Wiley \& Sons, 2007. p.1158-1161.

SRINIVASU, M.K.; RAJU, A.N.; REDDY, G.O. Determination of lovastatin and simvastatin in pharmaceutical dosage forms by MEKC. J. Pharm. Biomed. Anal, v.29, p.715$721,2002$.

UNITED STATES PHARMACOPEIA. 34. ed. Rockville: USP Convention, 2011. p.276-4230.

VADAS, E.B. Pharmaceuticals stability. In: GENNARO A.G. (Ed.). Remington: the science and pratice of pharmacy. Rio de Janeiro: Ed. Guanabara Koogan, 2004. p.1022-1031.

VIÇOSA, A.L.; CHATAH, E.N.; SANTOS, T.C.; JONES, L.F.J.R.; DANTAS, C.B.; DORNELAS, C.B.; DIAS, L.S. Bioequivalence studies and sugar-based excipients effects on the properties of new generic ketoconazole tablets formulations and stability evaluation by using direct compression method. Pharm. Dev. Technol., v.14, p.530$539,2009$.

WELLS, J. Pharmaceutical preformulation. In: AULTON, M.E. (Ed.). Pharmaceutics: the science of dosage form design. Edinburgh: Churchill Livingstone, 2005. p.113-138.

WILLIAMS, G.M.; IATROPOULOS, M.J.; WHYSNER, J. Safety assessment of butylated hydroxyanisole and butylated hydroxytoluene as antioxidant food additives. Food Chem. Toxicol., v.37, p1027-1038, 1999.

WILLIAMS, G.M.; IATROPOULOS, M.J. Evaluation of potencial human carcinogenicity of synthetic monomer ethyl acrylate. Regul. Toxicol. Pharmacol., v.53, p.6-15, 2009.

ZHANG, Y. Theoretical methods used in elucidating acitivity diferences of phenolic antioxidants. J. Am. Oil Chem. Soc., v.7, p.745-748, 1999.

Received for publication on $16^{\text {th }}$ February 2012. Accepted for publication on $12^{\text {th }}$ July 2012. 
